\title{
SURINAME IN BEELD
}

De jeugd van vroegeren tijd kreeg veel te hooren over Suriname. Verscheidene kinderboeken heb ik in dit Tijdschrift besproken, het laatst de "Vertellingen van een Surinaamschen vogel” door Christina van Gogh. Hier is een prent van ongeveer denzelfden leeftijd, nl. ook uit 1860, maar de blokken waarmede de prent is gedrukt, verzekerde mij een deskundige, zijn ouder. De titel luidt: „Prenten-magazijn voor de jeugd. No. 80. Aardrijkskunde. Suriname, bezitting der Nederlanders op het vasteland van Amerika. 65.000 inwoners.” Onderaan is gedrukt: „Prenten-Fabriek van D. Noothoven van Goor te Leiden." De prent, die tot de collectie van dr. H. D. Benjamins behoort, is van de soort die in mijn jeugd een cent kostte. De firma N. v. G. bestaat niet meer.

Voor het grafische gedeelte zijn vier blokken gebruikt en links bovenaan begint dit viertal met een „Kaartje van de kolonie Suriname", ongeveer $11 \mathrm{bij} 8 \frac{1}{2} \mathrm{cM}$. Het onderschrift luidt als volgt: „Doen wij nu eens een reisje door de kolonie Suriname, Hier hebt gij 1) Paramaribo, de hoofdstad der Nederlandsche Westindische bezittingen en de residentie-plaats van den Goeverneur-Generaal, aan de rivier de Suriname, met 16.000 inwoners. 2) Prins Willem Frederik. 3) Brandwacht. 4) Bramspunt. 5) Leiden. 6) Amsterdam. 7) Purmerende. 8) Sommelsdijk. 9) Oranjewoud. 10) Belair. 11) Piquet. 12) Armina. 13) Gouverneurs-lust. 14) Frederiksdorp. 15) De Joden-Savana. 16) Gelderland. 17) Blaauwenberg. 18) De Vierkinderen. 19) Groningen. 20) Batavia." Eenige rivieren komen uit het $Z$. naar de N.-kust geloopen, waar de „West Indische Oceaan" het land bespoelt. Drie dikke rivieren staan er op het kaartje, de Corrantijn, de Suriname en de Marowijne, en een menigte dunnere. Voorts is in het z.o. geschreven „Het Land der Boschnegers” en in het Z.W. „Het Land der Indianen”, en verspreid over het geheele gebied staan de nummers, waarmede men, met behulp van het onderschrift, de ligging der plantages kan opzoeken. Links op het kaartje is een stukje van Berbice te zien, rechts een smalle strook van Cayenne.

De houtsneden zijn gekleurd, geverfd met drie kleuren, geel, rood en blauw. Suriname heeft alleen een veeg geel gekregen. 
Maar „Het Waaggebouw te Suriname”, is beter bedeeld, kreeg drie vegen: blauw is het dak, wit bleef de eerste verdieping, rood werd de parterre-ruimte en geel het pleintje ervoor. Op den achtergrond de rivier met een vlot en een zeilschip; verder behooren tot de stoffage een wagen met paard, negerinnen met paantjes gekleed en een paar Europeanen. De belangrijkheid van deze Waag blijkt uit het onderschrift: „Onder de bijzondere gebouwen, die men te Parimaribo aantreft, telt men ook de Waag, een zeer net gebouw, in 1822 gesticht, in welks bovenste gedeelte de talrijke afdeeling van het Departement Paramaribo, der Maatschappij tot Nut van 't Algemeen, hare vergadering houdt."

Dan krijgen we te zien „Het fort Zeelandia”. Het „ligt op een geweerschots-afstand van Paramaribo, en is van een groote kazerne en ruime lokalen voorzien, op een van welke het eenige torentje staat, dat hier gevonden wordt. In $1664^{1}$ ) veroverde de Zeeuwsche kapitein Abraham Krijnszoon of Crijnssen deze kolonie, en versterkte de vesting, die hij naar Zeeland het fort Zeelandia heette, welken naam zij behouden heeft. De haven der stad wordt door het for t bestreken. De Goeverneur-Generaal J. C. Rijk heeft deze sterkte nog zeer verbeterd." Door een tuintje is het emplacement van de omgeving afgescheiden; kanonnen op wielen zijn naar de rivier gericht, waar een zeilschip is te zien en een statie-prauw wordt geroeid door zes man; dit vaartuig draagt een hooge kajuit en heeft een naar binnen gekrulde voorsteven. Verder weg vaart een kroes-kroes met hoog opgetaste lading.

Wat de auteur van den tekst bedoelt met de haven der stad die door het fort wordt bestreken, is niet duidelijk. Behalve de breede Suriname-rivier is daar in de buurt de uitmonding van de Sommelsdijksche kreek, die echter geen haven vormt. Het geheele fort heeft een veeg rood gekregen, het land buiten de versterking, waar een neger bezig is een groot vat voort te rollen, werd geel gekleurd, en een stuk van de rivier blauw. Vermoedelijk is bedoeld met deze hoogst primitieve kleuring, door de willekeurig met de hand aangebrachte verfstrepen de prent te verfraaien en aantrekkelijker te maken dan de zwartdruk zou zijn geweest. Het moet worden gezegd, dat men destijds reeds zonderlinge methoden van onderwijs had; want de heele opzet en de aanhef: „Doen wij nu eens een reisje door de kolonie Suriname" doen immers onderstellen, dat er een poging aanwezig was om de jeugd te onderrichten. Maar kon 't in iemands brein opkomen te onderstellen, dat deze

1) Moet zijn 1667. 
zotte tekst en deze malle prentjes haar iets zouden leeren omtrent Suriname?

Ten slotte de vierde houtsnede „De Houtgrond De Vierkinderen". Deze onderneming ,ligt aan de Tawaycoera-kreek, in een schilderachtig oord. Op den voorgrond ziet gij ook nog afgebeeld den Cottontree of zijdekatoenboom, met zijn wijd uitgebreide takken en breede sporen. Deze boom staat in hoog aanzien bij de inboorlingen." In het blauwe water van de kreek, onder den gelen boom baadt zich een karbouw. Vergeten is te vermelden wat een houtgrond is; waar men de Tawaycoera-kreek moet zoeken; wat er belangrijks is aan de cottontree; wat sporen zijn; of met „inboorlingen" de negers worden bedoeld. Overigens is de tekst zeer volledig.

Indertijd, in het opstel „West-Indische tentoonstelling” (W. I. Gids, Aug. 1920, 177), heb ik geschreven, dat de poging om aan de kinders een en ander te leeren omtrent de Koloniën niet iets bijzonders is van onze dagen. „Daargelaten dat de vorm wat vervelend is, de brieven saai en taai zijn, mag toch het denkbeeld wel aardig heeten om aan jongens die nog kinderboeken lezen eenig begrip te geven van den aard en de afkomst der menschen die ginds wonen, van de natuur die hen omringt, ook van de nederzettingen der Europeanen en hun bedrijf. Jammer dat de uitkomst niet was wat de opzet bedoelde: de Kareltjes en Hendrikjes hebben uit die brieven zoo goed als niets onthouden, en toen zij volwassen waren wisten zij evenveel van Suriname als op den dag na hunne geboorte". Deze prent die „Aardrijkskunde” heet is van hetzelfde laken een pak.

Inmiddels zijn de methoden van onderwijs verbeterd, zegt men, grondig gewijzigd. Maar een materie zoo vluchtig als kennis van Suriname schijnt niet vast te leggen: na de schooljaren verdampt zij, en voor goed. Tenzij de aard van het werk, de richting van de studie, het ambt anders eischen. Waarom zullen we het ons moeilijk maken om Suriname, wanneer alles best loopt zonder dat?

SN. 